\title{
Heat treatment for endocrinological investigations on plasma positive for human immunodeficiency virus (HIV)
}

\author{
M R HANCOCK, M L KNAPP, H C GHANY, P D MAYNE \\ From the Department of Chemical Pathology, Charing Cross and Westminster Medical School, London
}

SUMmARY The effects of heat treatment of serum samples on the hormone analyses used in this laboratory were studied. Total T4, testosterone, progesterone, and growth hormone were not systematically affected by heat treatment over the whole range of analyte concentrations studied; for thyroid stimulating hormone, no effect was noted on serum samples with concentrations of less than $10 \mathrm{mU} / 1$. Significant changes occurred in total T3, cortisol, follicle stimulating hormone, lutenising hormone, and prolactin.

It is suggested that with appropriate preliminary study, heat treated plasma samples may be used in endocrinological investigations without adversely affecting the diagnostic validity of the results.

The incidence of acquired immunodeficiency syndrome (AIDS) is increasing, with a prolonged survival period after detection of seroconversion, and a consequent increasing need for pathology investigations. Endocrinological analyses are particularly unsuited to the grade III containment facilities recommended for processing human immunodeficiency virus (HIV) positive samples. It has been suggested that heat inactivation $\left(56^{\circ} \mathrm{C}\right)^{1}$ of the virus may be used to reduce the risk of infection and allow analyses to be carried out under normal conditions. ${ }^{2-4}$

In these studies, scant attention was paid to hormone analyses, yet within the laboratory such tests are least amenable to containment due to the expense both of duplicating equipment and of carrying out small batch analyses.

The present study was undertaken to examine the effect of heat treatment on the hormone analyses carried out in our department.

\section{Material and methods}

For each assay 16 to 52 previously analysed plasma samples were selected to cover a wide range of concentrations. The samples, which had been stored at $-20^{\circ} \mathrm{C}$, were thawed and a $0.6 \mathrm{ml}$ aliquot heated at $56^{\circ} \mathrm{C}$ for 30 minutes and then cooled on ice for five

Accepted for publication 29 October 1986 minutes. Both the untreated (A) and heat treated (B) portions were stored at $-20^{\circ} \mathrm{C}$ until analysis. Just before assay all aliquots were centrifuged at $2500 \mathrm{rpm}$ for five minutes to remove turbidity. The untreated and treated portions of each sample were assayed in duplicate in the same batch (table 1). Appropriate human control sera were included at the beginning and end of each assay. Analyses were repeated if controls were outside acceptable limits $( \pm 2 \mathrm{SD})$

Results were analysed by Student's paired $t$ test.

\section{Results}

Table 2 shows the comparison of results obtained.

Total $\mathrm{T}_{4}$, testosterone, progesterone, and growth hormone were not systematically affected by heat treatment over the whole range of analyte concentrations studied. The standard deviation of the percentage difference in results after heat treatment, however, exceeded the interbatch coefficient of variation for testosterone and growth hormone by a factor of more than three, indicating an increased variability of results.

For thyroid stimulating hormone, no apparent effect of heat treatment was noted in samples with concentrations of less than $10 \mathrm{mU} / 1$, although a small, but significant, increase in thyroid stimulating hormone was noted after heat treatment in samples containing more than $10 \mathrm{mU} / 1$.

In the remaining hormone assays there were 
Table 1 Methods of hormone analysis

\begin{tabular}{|c|c|c|c|}
\hline Analyte & Method & Supplier & $\begin{array}{l}\text { Interbatch } \\
\text { coefficient of variation ( } \%)\end{array}$ \\
\hline $\begin{array}{l}\text { Total } \mathrm{T}_{4} \\
\text { Total } \mathrm{T}_{3} \\
\text { Thyroid stimulating hormone }\end{array}$ & $\begin{array}{l}\text { Single antibody RIA-charcoal separation } \\
\text { Double antibody RIA } \\
\text { Immunoradiometric assay }\end{array}$ & $\begin{array}{l}\text { (in house) } \\
\text { NETRIA } \\
\text { NETRIA }\end{array}$ & $\begin{array}{l}8 \cdot 2 \\
4 \cdot 7 \\
4 \cdot 0\end{array}$ \\
\hline $\begin{array}{l}\text { Cortisol } \\
\text { Testosterone }\end{array}$ & $\begin{array}{l}\text { Single antibody RIA-magnetic separation } \\
\text { Double antibody RIA-preliminary } \\
\text { extraction }\end{array}$ & $\begin{array}{l}\text { SERONO Diagnostic } \\
\text { St Thomas's Hospital }\end{array}$ & $\begin{array}{r}13.0 \\
6.9\end{array}$ \\
\hline Progesterone & Single antibody RIA-magnetic separation & Amersham UK & $12 \cdot 4$ \\
\hline $\begin{array}{l}\text { Follicle stimulating hormone } \\
\text { Lutenising hormone } \\
\text { Prolactin } \\
\text { Growth hormone }\end{array}$ & $\begin{array}{l}\text { Double antibody RIA } \\
\text { Double antibody RIA } \\
\text { Double antibody RIA } \\
\text { Double antibody RIA }\end{array}$ & $\begin{array}{l}\text { Chelsea Hospital } \\
\text { Chelsea Hospital } \\
\text { Guildhay UK } \\
\text { SAPU }\end{array}$ & $\begin{array}{l}4 \cdot 7 \\
4 \cdot 7 \\
7 \cdot 7 \\
8 \cdot 1\end{array}$ \\
\hline
\end{tabular}

NETRIA, North East Thames Regional Immunoassay; SAPU, Scottish Antibody Production Unit.

significant changes in results after heat treatment throughout the range of analyte concentrations studied. With the exception of prolactin, the differences were relatively small (less than $20 \%$ ).

\section{Discussion}

Although it is accepted that results of hormone assays are dependent to some extent on methodology, the radioimmunoassay or immunoradiometric assay used in this study is typical of that used in other laboratories, and it is therefore likely that our findings are applicable to most other laboratories using these techniques.

The revised Advisory Committee on Dangerious Pathogens guidelines on the safe handling of HIV specimens now permit the use of non-dedicated equipment and laboratory space for occasional, manual, analyses of these samples. ${ }^{5}$ Heat treatment sub- stantially reduces the risk of infection. ${ }^{67}$ There is still controversy, however, as to whether heat treatment at $56^{\circ} \mathrm{C}$ for 30 minutes inactivates the HIV virus completely. ${ }^{5}$

This study shows that most hormone assays, with the exception of prolactin, are either unaffected by heat treatment or are affected to a relatively minor extent that would not radically change clinical decision making.

We are grateful to the staff of the endocrinology section for their participation in this study and to Mrs J Payne for preparation of the manuscript.

\section{References}

I Spire B, Dormont D, Barre-Sinoussi F, Montagnier L, Cherman JC. Inactivation of lymphadenopathy-associated-virus by heat, gamma rays and ultraviolet light. Lancet 1985;i:188-9.

2 Lai L, Ball G, Stevens J, Shanson D. Effect of heat treatment of

Table 2 Summary of changes in plasma hormone concentration after heat treatment

\begin{tabular}{|c|c|c|c|c|c|c|}
\hline \multirow[b]{2}{*}{ Analyte $(n=)$} & \multirow[b]{2}{*}{ Units } & \multicolumn{2}{|l|}{ Untreated } & \multirow{2}{*}{$\begin{array}{l}\text { Mean difference } \\
\text { after heat } \\
\text { treatment }(\%)\end{array}$} & \multirow{2}{*}{$\begin{array}{l}S D \text { of } \\
\text { difference after } \\
\text { heat treatment }(\%)\end{array}$} & \multirow{2}{*}{$p$ value } \\
\hline & & Range & Mean & & & \\
\hline $\begin{array}{l}\text { Total } \mathrm{T}_{4}(27) \\
\text { Total } \mathrm{T}_{3}(19)\end{array}$ & $\begin{array}{l}\mathrm{nmol} / 1 \\
\mathrm{nmol} / 1\end{array}$ & $\begin{array}{l}9-395 \\
0.8-9.9\end{array}$ & $\begin{array}{l}135 \\
4 \cdot 1\end{array}$ & $\begin{array}{l}+1.5 \\
+9.8\end{array}$ & $\begin{array}{l}8 \cdot 1 \\
9 \cdot 8\end{array}$ & $\begin{array}{l}\text { NS } \\
<0.05\end{array}$ \\
\hline $\begin{array}{l}\text { Thyroid stimulating } \\
\text { hormone }(52)\end{array}$ & $\mathrm{mU} / \mathbf{I}$ & $\begin{array}{l}<0 \cdot 1-10 \cdot 0 \\
10 \cdot 1-54 \cdot 5\end{array}$ & $\begin{array}{r}2 \cdot 8 \\
33 \cdot 7\end{array}$ & $\begin{array}{l}+3.6 \\
+\quad 7.7\end{array}$ & $\begin{array}{l}7 \cdot 1 \\
8 \cdot 6\end{array}$ & $\begin{array}{l}\text { NS } \\
<0.05\end{array}$ \\
\hline $\begin{array}{l}\text { Cortisol (24) } \\
\text { Testosterone (25) } \\
\text { Progesterone (21) }\end{array}$ & $\begin{array}{l}\mathrm{nmol} / 1 \\
\mathrm{nmol} / 1 \\
\mathrm{pmol} / 1\end{array}$ & $\begin{array}{l}66-1045 \\
1 \cdot 3-25 \cdot 3 \\
5 \cdot 7-138 \cdot 4\end{array}$ & $\begin{array}{r}438 \\
8.5 \\
58.9\end{array}$ & $\begin{array}{l}+17.8 \\
+\quad 3.5 \\
+\quad 8.0\end{array}$ & $\begin{array}{l}19 \cdot 0 \\
18 \cdot 8 \\
22 \cdot 9\end{array}$ & $\begin{array}{l}<0.05 \\
\text { NS } \\
\text { NS }\end{array}$ \\
\hline $\begin{array}{l}\text { Follicle stimulating } \\
\text { hormone (20) } \\
\text { Lutenising hormone (16) } \\
\text { Prolactin (20) } \\
\text { Growth hormone (20) }\end{array}$ & $\begin{array}{l}\mathrm{mU} / 1 \\
\mathrm{mU} / 1 \\
\mathrm{mU} / 1 \\
\mathrm{mU} / 1\end{array}$ & $\begin{array}{l}3 \cdot 0-40 \cdot 0 \\
2 \cdot 6-50 \cdot 0 \\
291-1664 \\
0 \cdot 6-48 \cdot 5\end{array}$ & $\begin{array}{c}16 \cdot 1 \\
14 \cdot 1 \\
696 \\
11 \cdot 6\end{array}$ & $\begin{array}{l}-5.0 \\
-16.3 \\
-29.9 \\
-16.4\end{array}$ & $\begin{array}{r}5 \cdot 0 \\
19 \cdot 9 \\
18 \cdot 0 \\
30 \cdot 2\end{array}$ & $\begin{array}{l}<0.05 \\
<0.05 \\
<0.05 \\
\text { NS }\end{array}$ \\
\hline
\end{tabular}


plasma and serum on biochemical indices. Lancet 1985; 1457-8.

3 Houssein I, Wilcox H, Barron J. Effect of heat treatment on results for biochemical analysis of plasma or serum. Clin Chem 1985;31:2028-9.

4 Collinson PO, Stein PE, Light PK. Effect on biochemical values of heat treatment of plasma for the safe handling of samples from AIDS patients. Ann Clin Biochem 1986;23:102-3.

5 Advisory Committee on Dangerous Pathogens. LAV/HTLV III-the causative agent of AIDS and related conditions. Revised guidelines. London: DHSS, 1986.

6 Rouzioux C, Chamaret S, Montagnier L, Camelli V, Rolland G, Mannucci PM. Absence of antibodies to AIDS virus in haemophiliacs treated with heat-treated factor VIII concentrate. Lancet 1985;i:271-2.

7 Van der Meer J, Daenen S, Van Imhoff GW, De Wolf JTM, Halie MR. Absence of seroconversion for HTLV III in haemophiliacs intensively treated with heat treated factor VIII concentrate. Br Med J 1986;292:1049.

Requests for reprints to: Dr MR Hancock, Department of Chemical Pathology, Charing Cross and Westminster Medical School, The Westminster Hospital, 17 Page Street, London SW1P 2AR, England. 